\title{
DE

\section{PROCESS ORIENTATION AS A BASIS FOR INCREASING SUPPLY CHAIN MANAGEMENT MATURITY}

\author{
Marija Radosavljević \\ Univerzitet u Nišu, Ekonomski fakultet, Srbija \\ $\bowtie$ marija.andjelkovic@eknfak.ni.ac.rs
}

UDC
658.7
005
Original
scientific
paper

Received:

12.1.2015

Accepted:

24.9.2015

\begin{abstract}
Process management is an essential element of modern management models, at the enterprise level, but also at the supply chain level. However, the importance of process management is explicitly indicated by the process management maturity models, through analysis of the level of process orientation, or through analysis of the level of quality of process orientation components. Starting from the fact that competition in modern conditions often takes place between supply chains, process management maturity grows into supply chain management maturity. Some of the supply chain management maturity models are SCMAT model, $\mathrm{S}(\mathrm{CM}) 2$ model and SCPM3 model. In this paper the framework of another supply chain management maturity is formulated, by upgrading the SCOR model with process orientation, or SCORBPO model. This model involves analysis of the presence of supply chain management best practice, on one hand, and the presence of process orientation components, on the other hand. The aim of the research was to identify the maturity of enterprises in Serbia in applying supply chain management best practice, as well as process orientation components that are potential sources of competitive advantage or constraints for enterprises and supply chains. Analysis of justification of hypotheses is done by using correlation and regression analysis. The general conclusion is that between the presence of best practices and process orientation components there is a positive correlation, and that most of the process orientation components affect the implementation of supply chain management best practices.
\end{abstract}

Keywords: process orientation, supply chain, maturity, SCOR model, correlation and regression analysis. 


\section{Introduction}

Business process management is a popular topic at the beginning of the $21^{\text {st }}$ century, because it is very important from a practical point of view, but at the same time a significant challenge for scientists and theoreticians, primarily in the field of business management, but also from other social and technical disciplines, considering the multidisciplinary nature of the phenomenon.

The support to the acceptance of process approach as a response to dynamic environment is the fact that in the functional organization, each function observes the company's operations from its own perspective and focuses on achieving local optimum. Employees perform tasks to achieve the objectives of the specific function, or in order to meet the criteria defined by the managers of the function, without observing how their work contributes to creating value for customers.

The adoption of a process approach prevents sub-optimisation, which occurs due to the insufficient coordination and lack of transparency of process realization. At the same time, transparency should enable employees to understand how their work fits into the whole process and what is their contribution to the realization of the process and, ultimately, satisfying the needs of consumers. In this way, employees feel "involved" in what they do, but also responsible for the success of the company as a whole.

The most important characteristic of a process orientation is considered to be the identification of process owner, because it provides exceeding the greatest limitation of classical organization of the company - the question of competence and responsibility (Djuričin, Janošević, 2006). Process orientation means that the emphasis is not on the vertical distribution of power, but on horizontal cooperation in order to achieve the desired process performances. Therefore, the process orientation represents the condition for providing high performances (Devane, 2004). Business Process Management is defined as a holistic management approach, which is focused on the identification, definition, implementation, measurement, monitoring, analysis and continuous improvement of business processes of companies (De Oliveira et al., 2011). Business process management is actually the acceptance process orientation as a way of realization of all tasks in the company.

The transformation of resources within the company is performed through the series of interrelated and interacting processes, where the output of one is the input for another process. Seen from this perspective, it might be said that the company is a collection or network of processes that are used for the transformation of inputs into outputs (Spanyi, 2004). On the other hand, starting from general systems theory, according to which each company can be viewed as an open system that is in constant interaction with the environment, it can be 
said that the company is part of a larger system, in which, together with the other, related companies, it makes business network or popularly said supply chain. Similar to the company level, at the level of the network connection between the companies is established on the basis of business processes that go beyond the limits determined by the companies' activities. The expansion of process orientation from the company level to the corporate networks or supply chains occurs as a result of the frequent establishment of relations of competition between supply chains rather than between individual companies.

Previously mentioned points to the need to examine the aspects and possibilities of influence of the process orientation to supply chain management, which is a step forward compared to traditional observation of the effects of process orientation. For this reason, this paper, after pointing out the importance of the so-called mature business process management, clarifies the role and importance of a mature supply chain management, and the methodology and results of the research, which is the basis for testing the assumptions or hypothesis regarding the maturity of supply chain management.

\section{Business Process Management Maturity}

Process orientation is present to the significant extent in the theory and practice since the last decade of the last century, first through analyzing the business process or workflow (Jablonski, Bussler, 1996; Georgakopoulos, Hornick, Sheth, 1995), and then through the structuring of business processes and defining their inputs, outputs and the owner (Davenport, 1993; Johansson, 1993; knode, Schonberger, 2001; Hammer, 2002, Laguna, Marklund, 2005; Rummler Brache, 2012). As most authors emphasize, process orientation does not necessarily mean changing organizational structure, but involves the application of new principles and rules for behaviour of employees, especially managers. The success of the implementation of process orientation can be observed through the process management maturity concept.

The maturity of process management or the level of process orientation that the company has reached attracted the attention of many authors (Humphrei, 1988; Zairi, Ahmed, 1999; Maull et al., 2003; Fisher, 2004 Rosemann, de Bruin, 2005; Curtis, Alden 2007; Hamer, 2007; Van Looy et. al., 2011). It is believed that the first model of maturity in the true sense of the word was developed at Carnegie University, 1990. Years of research and analysis have opened new perspectives on maturity process management and led to the emergence of different models of business processes.

One of the best known is the model formulated by Rosemann and de Bruin (2005), which is known as Business Process Management Maturity Model. At the heart of this model there are six factors, identified based of the Delphi study, which are critical for the successful implementation of business processes, such 
as strategic alignment, process management, employee management, methods, information technology, and culture. The maturity of process management is determined exactly by the quality and the presence of these factors. Regarding the maturity of business process management, depending on what level most of the above factors are, the company can be at one of the following levels (McCormack et al., 2009): silo, tactical integration, process orientation, optimized enterprise and intelligent network.

The maturity of process management can be represented as a combination of coverage and proficiency, which basically boils down to a combination of effectiveness and efficiency. In terms of process management, coverage or effectiveness refers to the extent to which the principles of business process management are implemented and applied, while the proficiency or efficiency shows the quality of implementation of the principles of business process management. Achieving higher levels of maturity implies the improvement of both, coverage and proficiency. Coverage can be "measured", based on: the number of processes that are managed, the number (and structure) employees involved in process management, connectivity of process management with other concepts and techniques. Proficiency can be "measured" on the basis of: frequency of realization of projects for process improvement, speed of implementation of process improvement, timely response to the demands of process management (Rosemann et al., 2011).

A good way for demystifying maturity of business processes and, more importantly, a good way operationalization of identifying the level of maturity of the processes themselves, is the process capability analysis. Process capability shows the extent to which the process provides results whose performance are inside of control or specification limits. For measuring the ability of the process usually is used process capability index $(\mathrm{Cp})$. The process capability index is a ratio of difference between the upper (USL) and the lower limit specifications (LSL), which is marked as prescribed tolerance, and 6 standard deviations, which is referred as natural tolerance (Chandra, 2001).

Based on the above mentioned, it is possible to conclude that there is a difference between the maturity of process management and maturity of the processes themselves. More specifically, in order to attain a certain level of maturity of the process management, it is necessary that the processes themselves reach a certain level of maturity, especially in terms of the quality of implementation and the quality of output produced through them. Transferred to the field of maturity management, improvement of business processes can be explained as a continuous movement towards higher levels of maturity (Figure 2 ). In fact, one can say that the increase in the process capability factor of process management maturity., 
Figure 1 From Process Capability to Process Management Maturity

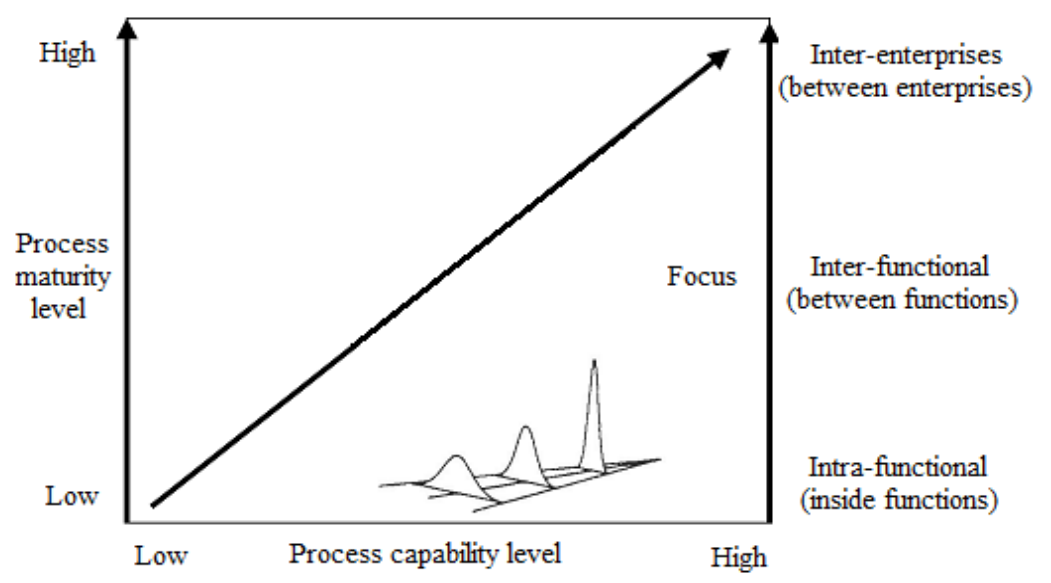

Adapted according to: Lockamy, McCormack, 2004a, p. 274

Based on the above explained, it can be said that the levels of maturity management show the evolution of the company from the state in which it is at the beginning of the process maturity jouney, and in which processes are not clearly defined, have no satisfactory level of competence, and there are no adequate standards and methods to supporting process management, till the state that reflects to a higher maturity level and seriousness in the implementation of relevant principles, standards and methods. Crossing the road from the current to the desired state, may be facilitated by the maturity models, as a kind of evolutionary map or control panel to monitor the corresponding parameters and directing of process improvement. These models provide the assessment of the evaluation of maturity level in the implementation of process orientation, and also identification of potential ways for increasing the maturity level.

\section{Supply Chain management Maturity: A Review of Previous Research}

Although management maturity, as a phenomenon, commonly is associated with process management at the enterprise level, the authors speak more and more about supply chain management maturity. According to the opinion of certain authors "main advantages of the process or open business organization are reflected in enabling efficient integration and coordination not only between the parts of an organization, but also with external stakeholders" (Petkovic et al., 2006, p. 223). This opinion shows that process orientation and process management should allow a smooth flow of material and information throughout the enterprise and between the enterprise and its partners, primarily suppliers and customers. This means that with the maturity of the process, as well as the maturity of process management at the enterprise level, it is 
necessary to develop process management at the level of the supply chain, thus opening up a new area of research in the $21^{\text {st }}$ century - the supply chain management maturity.

The supply chain management maturity is not an objective of such a great number of authors, but still enough to provide certain number of supply chain management maturity models (Lockamy, McCormack 2004a; Jaklic et al., 2006; Vaidyanathan, Howell, 2007; Netland et al., 2007; McCormack et al., 2008). When it comes to assessment of supply chain management maturity the famous models are: SCMAT model (Netland et al., 2007), S(CM) ${ }^{2}$ model (Garcia, 2008) and SCPM3 model (De Oliveira et al., 2011). Similarly as in case of models of business process maturity, these models consist of a large number of elements, which are grouped into specific categories (categories 7-13). The elements shown in the models actually represent the best practices in the field of supply chain management, so the essence of the models is the assessment of the representation and the application of best practices, and identification of weaknesses of a particular supply chain in relation to world class.

In addition to these models, very interesting is the model, which is the basis of methodology for the study presented in this paper, which is founded on wellknown and, in supply chain management, widely accepted, the SCOR model. SCOR is the acronym of the model's full name the Supply-Chain Operations Reference model. This model was formulated by the Supply Chain Council, founded in 1996. The first version of the model appeared in the very next year, in 1997 (www.supply-chain.org). According to the Council, SCOR model is the integration of business process reengineering, benchmarking and process performance measurement.

The goal of establishing supply chain management maturity model, based on the SCOR model, is to increase the efficiency of supply chains through the implementation of the process approach. Given that it examines performances of the companies, as parts of the supply chain, through the phase of the SCOR model implementation, based on the process orientation, this model could be called $\mathrm{SCOR}^{\mathrm{BPO}}$.

Figure $2 \mathrm{SCOR}^{\mathrm{BPO}}$ model - the framework of the research

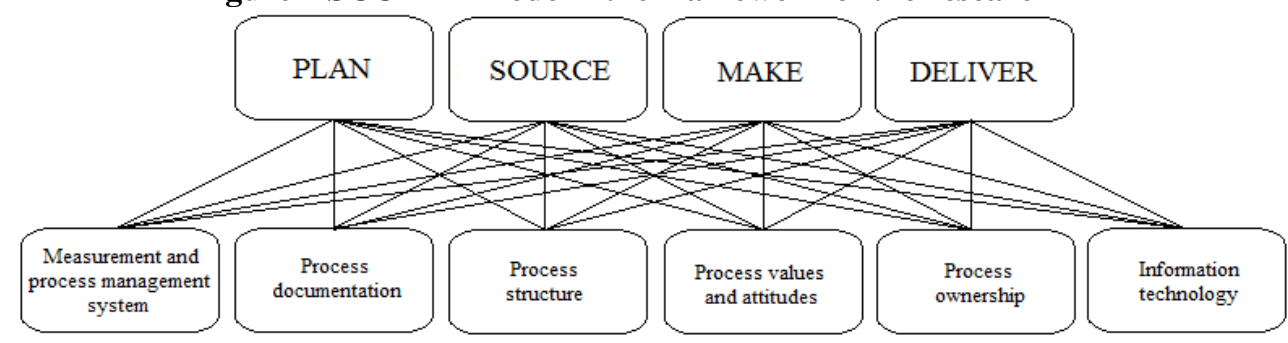


According to the SCOR model, there are five types of processes, such as: plan, source, make, deliver and return (Lockamy, McCormack, 2004b). Planning refers to the processes affecting the balance between aggregate demand and supply in order to meet the requirements of the processes that follow (source, make, deliver). Supply includes procurement processes for providing adequate resources or providing services from other enterprises for the successful implementation of processes within make and deliver processes. The processes that involve the transformation of resources into products and / or services intended for meeting the identified demand belong to the group make. The fourth type includes those processes that enable the products and services find their way to the market, or to the users, thanks to transport and distribution, which means that it is about the delivery processes. Although the fifth type of processes is sometimes omitted, at the time when customer protection is at a high level, this type of processes is necessary, and refers to the processes of return or receiving returned products, which means that they relate to the extension of relationship with customers after the delivery. These types of processes must reach a certain level of maturity in order to secure the undisturbed flow through the supply chain, passing through the following levels: ad hoc, defined, connected, integrated, extended.

The second segment of $\mathrm{SCOR}^{\mathrm{BPO}}$ model focuses on process orientation components, namely: measurement and process management system, process documentation, process structure, process values and attitudes, ownership of processes, information technology (Lockamy, McCormack, 2004; McCormack et al. 2009).

Measurement and process management system means that it is necessary to measure the performance of the process, during their implementation, as well as the performance of the final result, that the performances are guided by customers' demands, but what is equally important, that it is necessary to reward employees based on the results achieved under the improvement of the process.

Process documentation is a very important component of a formal process orientation. It refers to the visual presentation of the process, including its activities, resources, and connections between them. In addition, the role of process documentation is in the fact that it spreads the same language - the language of processes throughout the enterprise, so that all employees can follow what is happening during the implementation of the process, including those who are directly involved in the implementation, as well as other employees, which is a prerequisite for bridging the functional gap.

Process structure is a framework which defines the role and responsibility of a team for supply chain management in terms of bridging the problems related to the functional divisions within the supply chain and the expansion of process thinking through the supply chain. Also, process structure includes the 
establishment of horizontal teams, the division of responsibilities and the division of roles between the partners. This approach is essential to supply chain management in order to provide managing of the chain in the true sense of the word.

Process values and attitudes are the most important and at the same time the most abstract component of process orientation. These include changing business culture, promoting teamwork, trust among partners, dedication to the job, but also to the objectives and strategy of the supply chain.

Process ownership relates primarily to defining the position of employees in terms of owners of processes and the owners of activities. In this way it is provided that the employees observe processes that they manage or activities that they performed as their property, and, therefore, strive to realize them with maximum dedication. Thus, the emphasis is on horizontal, rather than on vertical, responsibilities of employees.

Information technology is a component that represents the connective tissue for process orientation. It enables operationalization of the previously mentioned components of process orientation, with the emphasis on performance measurement and processes management system and process structure.

\section{Research Methodology}

Authors who have recognized the importance of supply chain management, on one hand, and process orientation, on the other hand (Lockamy, McCormack 2004a; Jaklic et al., 2006; Vaidyanathan, Howell, 2007; Netland et al., 2007; McCormack et al., 2008; Garcia, 20008, De Oliveira et al., 2011), in their researches analyze the factors of supply chain management maturity, especially from the perspective of process orientation. However, most of these researches show the results from developed countries, and confirm that the companies as parts of supply chains in this region largely are characterized by a high level of supply chain management maturity. Regarding the trend of globalization and the inclusion of enterprises from developing countries in global supply chains, a need for assessing the presence of process orientation, as well as the possibility of applying best practices in supply chain management in these companies appeared. If companies are better "prepared", the process of integration in the supply chain will be significantly facilitated.

Given the importance of supply chain management and process orientation, the aim of the research presented in this paper is to identify the maturity of enterprises in the Republic of Serbia in the implementation of best practice of supply chain management. At the same time, it is important to identify the components of process orientation, which are potential sources of competitive 
advantages, on one hand, and those that are "weak links" and restrictions for companies or supply chains.

The research is based on the framework formulated by well-known authors in the field of supply chain management maturity, which are Lockamy and McCormack. Starting from the best practices of supply chain management within each of the four segments of the SCOR model, these authors have identified a number of issues on which it is possible to assess the maturity of supply chain management (Lockamy, McCormack, 2004b, pp. 1214-1216).

On the other hand, in order to complete the analysis, it is necessary to analyze the presence of process orientation. Components of process orientation are analyzed based on the issues that include the following topics (Lockamy, McCormack, 2004a):

1. Measurement and process management system - defining criteria, customer requirements, rewards to employees.

2. Process documentation - defining processes, documenting processes, understanding the process.

3. Process structure - the teams, collaboration, integration.

4. Process values and attitudes - focus on consumers, credibility, trust.

5. Process ownership - the owners of processes and activities, authority, commitment, responsibility.

6. Information technology - correlation, coherence, timeliness.

The initial hypothesis $\left(\mathrm{H}_{0}\right)$ is that these components of process orientation affect the elements of the SCOR model, or the application of best practices defined by the SCOR model. The accompanying hypotheses are as follows:

- H1: There is a positive correlation between the elements of the SCOR model.

- H2: There is a positive correlation between the components of process orientation.

- H3: The components of process orientation determine the maturity of SCOR model elements.

In order to test the formulated hypotheses appropriate methods of statistical analysis have been used. In addition to descriptive statistics, correlation analysis and regression analysis have been applied. The analysis was performed using SPSS software (version 17).

The study involved 244 companies from the Republic of Serbia, although the questionnaire was distributed to 1000 managers selected by random sampling, which makes a response rate of $24.4 \%$. The response rate is satisfactory, especially if one takes into account that the condition for inclusion of companies in the sample was belonging to a supply chain, while the additional criteria was the presence of process orientation in the enterprise. For this reason, a large number of managers are not "competent" to fill in 
questionnaires, so the companies they work with have not entered into the sample based on which the analysis was conducted. Representation of the best practice of supply chain management and process orientation has been evaluated based on five-point Likert scale, where ratings have the following meanings: 1 - never, 2 - rarely, 3 - sometimes, 4 - frequently, 5 - always. Below are shown the major results of the analysis of the collected data.

\section{Research Results and Discussion}

As noted, the model on which was the conducted research is based on includes analysis of the distribution of supply chain management best practice, on one hand, and components to process orientation, on the other hand. Representation of best practices is assessed basis on 94 questions grouped into four categories according to the type of process within the SCOR model, namely: plan, supply, make and deliver (Lockamy, McCormack, 2004b). On the other hand, the presence of process orientation was assessed based on 18 questions within 6 mentioned components.

According to the results of descriptive statistics, best practice in supply chain management has largely represented in terms of the Plan and Supply process (average ratings 3.86). Something worse result is noticed for the processes within group Make (3.37), while Deliver is characterized by the lowest average mark (2.87). When it comes to the presence of components of process orientation, the mostly present is the third component Process structure (3.81), followed by Process values and attitudes (3.41) and Process ownership (3.12), while the lowest average grades are recorded for Information Technology (2.95) and Process documentation (2.97). Although not insignificant, the average marks themselves are not sufficient to draw conclusions. In order to ensure additional information to conclude in the sense of hypotheses acceptance or rejection, correlation analysis has been used.

The correlation coefficients for the first group of data relating to the Plan, which show the dependence between the data, are in the range of 0.350 to 0.871 , confirm the assumption about their connection. In the same way it was found that the correlation coefficients within Source are between 0.386 and 0.928, within Make between 0.489 and 0.950 , while Deliver is characterised by the correlation coefficients between 0.388 and 0.940 . These results indicate the possibility of generalizing the data or the using of new variables, which are the result of averaging the individual variables from each of the four groups (plan, supply, make, deliver). The same procedure was applied when it comes to the components of process orientation, and similar conclusions are the condition for averaging of these variables, too.

In order to answer the first two supporting hypotheses and then to the primary hypothesis correlation analysis has been performed between variables 
related to the SCOR model, and then between the variables related to the BPO, as the parts of the applied model.

The results of correlation analysis, for variables on which supply chain management maturity is assessed, are encouraging because correlation coefficients indicate a significant correlation (correlation coefficients have high or very high value). This means that, in those companies in which the application of best practice in supply chain management is present, this application is uniform in all segments (plan, source, make and deliver).

Table 1 Correlation Analysis: Application of Best Practice According to the Types of Processes and Components of Process Orientation*

\begin{tabular}{|c|c|c|c|c|c|}
\hline & & AVEP & AVES & AVEM & AVED \\
\hline \multirow{3}{*}{ P1 } & $\begin{array}{l}\text { Correlation } \\
\text { coefficient }\end{array}$ & $.868(* *)$ & $.796(* *)$ & $.841(* *)$ & $.868(* *)$ \\
\hline & Significance level & .000 & .000 & .000 & .000 \\
\hline & Sample size & 244 & 244 & 244 & 244 \\
\hline \multirow{3}{*}{ P2 } & $\begin{array}{l}\text { Correlation } \\
\text { coefficient }\end{array}$ & $.870(* *)$ & $.792(* *)$ & $.820(* *)$ & $.864(* *)$ \\
\hline & Significance level & .000 & .000 & .000 & .000 \\
\hline & Sample size & 244 & 244 & 244 & 244 \\
\hline \multirow{3}{*}{ P3 } & $\begin{array}{l}\text { Correlation } \\
\text { coefficient }\end{array}$ & $.696(* *)$ & $.653(* *)$ & $.735(* *)$ & $.725(* *)$ \\
\hline & Significance level & .000 & .000 & .000 & .000 \\
\hline & Sample size & 244 & 244 & 244 & 244 \\
\hline \multirow{3}{*}{ P4 } & $\begin{array}{l}\text { Correlation } \\
\text { coefficient }\end{array}$ & $.413(* *)$ & $.478(* *)$ & $.511(* *)$ & $.477(* *)$ \\
\hline & Significance level & .000 & .000 & .000 & .000 \\
\hline & Sample size & 244 & 244 & 244 & 244 \\
\hline \multirow{3}{*}{ P5 } & $\begin{array}{l}\text { Correlation } \\
\text { coefficient }\end{array}$ & $.787(* *)$ & $.738(* *)$ & $.793(* *)$ & $.768(* *)$ \\
\hline & Significance level & .000 & .000 & .000 & .000 \\
\hline & Sample size & 244 & 244 & 244 & 244 \\
\hline \multirow{3}{*}{ P6 } & $\begin{array}{l}\text { Correlation } \\
\text { coefficient }\end{array}$ & $.798(* *)$ & $.764(* *)$ & $.795(* *)$ & $.776(* *)$ \\
\hline & Significance level & .000 & .000 & .000 & .000 \\
\hline & Sample size & 244 & 244 & 244 & 244 \\
\hline
\end{tabular}

** Correlation is significant 0.01 (two-sided).

* AVEP - Plan (average value determined on the basis of variables in this type of process), AvES - Supply (average value determined on the basis of variables in this type of process), AVEM Make (average value determined on the basis of variables in this type of process), AVED Deliver (average value determined on the basis of variables in this type of process), P1 Measurement and processes management system, P2 - Process documentation, P3 - Process structure, P4 - Process values and attitudes, P5 - Process ownership, P6 - Information technology. 
The following analysis concerns the relationships of the components of process orientation. According to the results of the analysis it may be concluded that between the observed components there is a high correlation, because in most cases the correlation coefficients exceed 0.500. In the first two components (Measurement and process management system and Process documentation) correlation coefficients with the other components were slightly higher compared to the others, while the lowest values of this coefficient characterises fourth component, or Process values and attitudes. Based on the foregoing analysis, it became obvious that the connection between the components of process orientation and application of supply chain management best practice also can be assessed by correlation analysis (Table 1).

Correlation analysis has shown that there is a correlation between the presence of components of process orientation and application of supply chain management best practice, because the value of the correlation coefficients are ranging from 0.413 up to 0.870 .

In addition to the results provided through correlation analysis, regression analysis has been performed. This analysis has been used to show the extent to which certain components of process orientation affect the application or representation of supply chain management best practice. The following tables contain the results of regression analysis. Based on Beta value and significance may be realized whether the application of supply chain management best practice by the elements of SCOR model is conditioned by the presence of process orientation components.

Table 2 Regression Analysis: Dependent Variable AVEP

\begin{tabular}{||c|c|c|c||}
\hline $\begin{array}{c}\text { Process orientation } \\
\text { components }\end{array}$ & $\begin{array}{c}\text { Standardized } \\
\text { coefficient - Beta }\end{array}$ & $\mathrm{t}$ & Significance \\
\hline P1 & .120 & 1.784 & .076 \\
\hline P2 & .427 & 6.734 & .000 \\
\hline P3 & .082 & 3.511 & .001 \\
\hline P4 & -.008 & -.251 & .802 \\
\hline P5 & .164 & 4.939 & .000 \\
\hline P6 & .326 & 10.655 & .000 \\
\hline
\end{tabular}

Table 3 Regression Analysis: Dependent Variable AVES

\begin{tabular}{|c|c|c|c|}
\hline $\begin{array}{c}\text { Process orientation } \\
\text { components }\end{array}$ & $\begin{array}{c}\text { Standardized } \\
\text { coefficient - Beta }\end{array}$ & $\mathrm{t}$ & Significance \\
\hline P1 & .080 & .859 & .391 \\
\hline P2 & .361 & 4.119 & .000 \\
\hline P3 & .183 & 5.647 & .000 \\
\hline P4 & -.004 & -.086 & .932 \\
\hline P5 & .142 & 3.090 & .002 \\
\hline P6 & .340 & 8.033 & .000 \\
\hline
\end{tabular}


Table 4 Regression Analysis: Dependent Variable AVEM

\begin{tabular}{||c|c|c|c|}
\hline $\begin{array}{c}\text { Process orientation } \\
\text { components }\end{array}$ & $\begin{array}{c}\text { Standardized } \\
\text { coefficient - Beta }\end{array}$ & $\mathrm{t}$ & Significance \\
\hline P1 & .164 & 2.318 & .021 \\
\hline P2 & .205 & 3.083 & .002 \\
\hline P3 & .179 & 7.283 & .000 \\
\hline P4 & .110 & 3.117 & .002 \\
\hline P5 & .195 & 5.621 & .000 \\
\hline P6 & .317 & 9.897 & .000 \\
\hline
\end{tabular}

Table 5 Regression Analysis: Dependent Variable AVED

\begin{tabular}{|c|c|c|c||}
\hline $\begin{array}{c}\text { Process orientation } \\
\text { components }\end{array}$ & $\begin{array}{c}\text { Standardized } \\
\text { coefficient - Beta }\end{array}$ & $\mathrm{t}$ & Significance \\
\hline P1 & .129 & 1.839 & .067 \\
\hline P2 & .398 & 6.060 & .000 \\
\hline P3 & .156 & 6.405 & .000 \\
\hline P4 & .051 & 1.456 & .147 \\
\hline P5 & .122 & 3.543 & .000 \\
\hline P6 & .291 & 9.183 & .000 \\
\hline
\end{tabular}

Based on the values of beta coefficients and levels of significance, it can be concluded that at least "influential" process oriented components are first and fourth, respectively Measurement and process management system and Process values and attitudes. More specifically, the application of best practices within the Plan has shown no statistically significant correlation with the first and the fourth component of process orientation, and a similar result, or the result with the same meaning occurs with the application of best practice within the Source and Deliver. When it comes to Make, all components of process orientation affect the application of supply chain management best practice. One might say that these results confirm the results of the correlation analysis, suggesting the influence of process orientation on the application of supply chain management best practice, but also indicate the existence of problems with some components of process orientation (first and fourth), because the impact is lacking, which means that these components are neglected or not implemented in the right way.

\section{Conclusion}

In modern conditions, competitive advantage is created by establishing the appropriate combination of resources and capabilities (within the enterprise business process), but even more by adequate connection and cooperation with partners who are part of the company's supply chain. In this way, the issue of competitiveness is transferred from enterprises to the supply chain. For this 
reason, the focus of the researchers in the field of business management should be finding ways for transformation and application of proven concepts and tools at the level of the supply chain.

One of the models that is considered as a combination of business process reengineering, benchmarking and performance measurement process, and which is applied at the level of the supply chain, is the SCOR model. Although very important segment of this model is clustering processes into four categories (Plan, Source, Make, Deliver) for exploring the possibility of applying the maturity model at supply chain level, equally significant is the segment related to the components of process orientation (Measurement and process management system, Process documentation, Process structure, Process values and attitudes, Process ownership, Information Technology). Based on this model authors have come to some conclusions regarding the supply chain management maturity level in enterprises in the Republic of Serbia.

When it comes to descriptive statistics, it seems important that the lowest average score was recorded for the last component of process orientation, Information technology. The conclusion is that this component should be developed since it represents a kind of constraint for the application of process orientation in the context of adoption and application of supply chain management best practice. On the other hand, when it comes to implementing best practices, according to the results of descriptive statistics, in the companies in the sample it is the least represented when it comes to processes related to Deliver, indicating in which areas occur the sources of problems in functioning of supply chains.

The analysis showed that the correlation coefficients, both between the types of processes (Plan, Source, Make, Deliver), and between the components of process orientation, in most cases are high. For the types of processes, there are no exceptions, while for the process orientation there is an exception - the fourth component - Process attitudes and values, for which the correlation coefficients are slightly lower (from 0.299 to 0.387 ) compared to the others. To the similar conclusion leads correlation analysis which was investigated in the connection between the representation of best practice according to the types of processes and process orientation components.

Regression analysis showed that the most of the components of process orientation affect the representation and implementation of best business practices. For all types of processes beta coefficients and significance level point to the existence of this influence. However, it can be seen that the influence of component Process values and attitudes is present only for the Make processes, while for the other types of processes, this component has no effect.

After connecting the previous analysis with the results of descriptive statistics, showing that the two aforementioned components have the lowest 
average rating (as an indicator of the representation in the business practices of companies in the sample), the conclusion is that these two components are present, but they are not implemented properly or do not comply with other components of process orientation. If one takes a look at the results of the correlation analysis for the process orientation components can be concluded that the fourth component - Process values and attitudes is not significantly associated with other components, and this can be accepted as an explanation. On the other hand, the correlation coefficients with the first component Measurement and process management system are high, which means that the activities under this component are not implemented adequately, and that the problems have operational nature.

For further research in this area an application of cluster analysis could be significant. By grouping of companies in the sample in certain clusters, the results of this kind of analysis would suggest the causes of the application of supply chain management best practice, independently of process orientation, or except from process orientation. In addition, it would be interesting to compare the results of analysis conducted in developing country, such as the Republic of Serbia, with the results of similar studies carried out in the developed countries, which would provide a more detailed understanding of the limitations and possibilities of application of supply chain management best practice.

\section{References}

Chandra, J. (2001) Statistical Quality Control, Washington: CRC Press LLC.

Curtis, B. and J. Alden (2007) "The Business Process Maturity Model: What, Why and How", BPTrends Column, 2: 1-4.

Davenport, T. (1993) Process Innovation: Reengineering work through information technology, Boston: Harvard Business School Press.

Devane, T. (2004) Integrating Lean Six Sigma and High-Performance Organizations: Leading the charge toward dramatic, rapid, and sustainable improvement. San Francisco: John Wiley \& Sons.

De Oliveira, M. P. V., M. B. Ladeira, and K. P. McCormack (2011) “The Supply Chain Process Management Maturity Model-SCPM3", in Önkal, D. and E. Aktas (eds.), Supply Chain Management-Pathways for Research and Practice. Rijeka: InTech, pp. 201-218.

Đuričin, D. and S. Janošević (2006) Menadžment i strategija, Beograd: Ekonomski fakultet.

Fisher, M. (2004) "The Business Process Maturity Model: A Practical Approach for Identifying Opportunities for Optimization”, BPTrends, 9: 1-7.

Garcia, H. (2008) A Capability Maturity Model to Assess Supply Chain Performance: Doctoral dissertation. Miami: Florida International University. 
Georgakopoulos, D., M. Hornick, and A. Sheth (1995) An Overview of Workflow Management: From Process Modeling to Workflow Automation Infrastructure, Distributed and Parallel Databases, 3: 119-153.

Hammer, M. (2002) „Process Management and the Future of Six Sigma“, MIT Sloan Management Review, 43 (2): 26-33.

Hammer, M. (2007) "The Process Audit", Harvard Business Review 85 (4): 1-17.

Humphrey, W. (1988) "Characterizing the software process: a maturity framework", IEEE Software 2 (5): 73-79.

Jablonski, S. and C. Bussler (1996) Workflow Management: Modeling Concepts, Architecture, and Implementation, San Francisco: International Thomson Computer Press.

Jaklic, J., P. Trkman, A. Groynik and M. Stemberger (2006) "Enhancing lean supply chain maturity with business process management", Journal of information and organizational sciences 30 (2): 205-223.

Johansson, H., et al. (1993) Business Process Reengineering: BreakPoint Strategies for Market Dominance, New York: John Wiley \& Sons.

Knod, E. M. and R. J. Schonberger (2001) Operations Management: Meeting Customers' Demands, Boston: McGraw-Hill.

Laguna, M. and J. Marklund (2005) Business Process Modeling: Simulation and Design, New Jersey: Pearson Education.

Lockamy III, A. and K. McCormack (2004a) "The development of a supply chain management process maturity model using the concepts of business process orientation", Supply Chain Management: An International Journal 9(4): 272-278.

Lockamy III, A. and K. McCormack (2004b) "Linking SCOR planning practices to supply chain performance: An exploratory study", International Journal of Operations \& Production Management 24 (12), 1192-1218.

Maull, S., D. Tranfield, and W. Maull (2003) Factors characterising the maturity of BPR programmes, International Journal of Operations \& Production Management 23 (6): 596-624.

McCormack, K., M. B. Ladeira, M. P. V. de Oliveira (2008) "Supply chain maturity and performance in Brazil", Supply Chain Management: An International Journal 13 (4): $272-282$

McCormack, K. et al. (2009) "A global investigation of key turning points in business process maturity", Business Process Management Journal 15 (5): 792-815.

Netland, T. H., E. Alfnes, and H. Fauske (2007) "How mature is your supply chain?-A supply chain maturity assessment test", 14th International EurOMA Conference Managing Operations in an Expanding Europe (EurOMA 2007), June 2007, Ankara, Turkey, 17-20.

Petković, M., N. Janićijević, and B. Bogićević Milikić (2006) Organizacija, Beograd: Centar za izdavačku delatnost Ekonomskog fakulteta.

Rosemann, M. and T. De Bruin (2005) "Application of a holistic model for determining BPM maturity", BPTrends 2: 1-21.

Rosemann, M., T. De Bruin, and T. Hueffner, and M. Rosemann (2004) "A Model for Business Process Management Maturity”, In Elliot,, Williams,, Williams,, \& 
Pollard, (eds.) Proceedings fo the 15th Annual Australasian Conference on Information Systems (ACIS) 2004, 1-3 December 2004, Hobart, Tasmania, 1-7.

Rummler, G. A. and A. P. Brache (2012). Improving performance: How to manage the white space on the organization chart. New York: John Wiley \& Sons.

Spanyi A. (2004) „Beyond Process Maturity to Process Competence“, BPTrends, 6: 1-5.

Van Looy, A., M. De Backer, and G. Poels (2011) "Defining business process maturity: A journey towards excellence", Total Quality Management \& Business Excellence 22 (11): 1119-1137.

Vaidyanathan, K. and G. Howell (2007) "Construction supply chain maturity modelconceptual framework", 15th IGLC Conference Lean Construction: A New Paradigm for Managing Capital Projects, 15 July 2007, Michigan, USA, 170-180.

Zairi, M. and P. K. Ahmed (1999) "Benchmarking maturity as we approach the millennium?”, Total Quality Management 10 (4-5): 810-816.

www.supply-chain.org

\section{PROCESNA ORIJENTACIJA KAO OSNOV POVEĆANJA ZRELOSTI UPRAVLJANJA LANCEM SNABDEVANJA}

Apstrakt: Upravljanje procesima neizostavni je element savremenih upravljačkih modela, na nivou preduzeća, ali i na nivou lanca snabdevanja. Ipak, na značaj upravljanja procesima eksplicitno ukazuju modeli zrelosti upravljanja procesima, kroz analizu nivoa procesne orijentacije, odnosno kroz analizu nivoa kvaliteta komponenata procesne orijentacije. Polazeći od činjenice da se konkurencija u savremenim uslovima sve češće odvija izmedju lanaca snabdevanja, zrelost upravljanja procesima prerasta u zrelost upravljanja lancem snabdevanja. Neki od modela zrelosti upravljanja lancem snabdevanja su SCMAT model, S(CM) ${ }^{2}$ model i SCPM3 model. U radu je formulisan okvir još jednog modela zrelosti upravljanja lancem snabdevanja, oplemenjivanjem SCOR modela procesnom orijentacijom, odnosno SCORBPo model. Ovaj model podrazumeva analizu zastupljenosti najbolje prakse upravljanja lancem snabdevanja, s jedne strane, i prisustvo komponenata procesne orijentacije, $\mathrm{s}$ druge strane. Cilj istraživanja je identifikovanje zrelosti preduzeća u Srbiji u primeni najbolje prakse upravljanja lancem snabdevanja, kao i komponenata procesne orijentacije koje predstavljaju potencijalne izvore konkurentske prednosti ili ograničenja za preduzeća i lance snabdevanja. Testiranje hipoteza izvršeno je primenom korelacione i regresione analize. Generalni zaključak je da izmedju zastupljenosti najbolje prakse i komponenata procesne orijentacije postoji pozitivno slaganje, kao i da najveći broj komponenata procesne orijentacije utiče na primenu najbolje prakse upravljanja lancem snabdevanja.

Ključne reči: procesna orijentacija, lanac snabdevanja, zrelost, SCOR model, korelaciona i regresiona analiza. 